\title{
放射線による消化管障害10例の治療経験
}

国立津病院外科

富田隆矢野隆柌日高直昭

三重県厚生連中勢総合病院外科

岡田喜克岩崎誠五嶋博道

\section{MANAGEMENT OF RADIATION INJURIES OF 10 CASES OF}

\section{GASTROINTESTINAL TRACTS}

Takashi TOMIDA, Takashi YANO and Naoaki HIDAKA

Department of Surgery, Tsu National Hospital

Yoshikatsu OKADA, Makoto IWASAKI and Hiromichi GOSHIMA

Departement of Surgery, Chusei General Hospital

放射線照射による晚期消化管障害10例を経験した。胃十二指腸潰瘍 2 例, 腸閉塞 4 例， 直腸出血 4 例で, 全例に保存的治療や局所安静のため人工肛門造設が施行された。しか しこれらの方法では治瘏傾向に乏しく，その後障害消化管の切除された 4 例は良好な経 過をたどっているのに対し，非切除例では長期間各症状の持続が認められている.

晚期障害は vasculo connective tissue の障害が主役をなすため進行性の病变で，保存 的療法による完全治瘁は望めない。したがって障害消化管の積極的切除が推奖されてい るが，現実には切除困難な症例が多い。

今後，放射線照射による障害発生の予防対策については十分な検討が必要であると思 われた。

索引用語：放射線消化管障害, 晚期放射線障害

はじめに

放射線治療後に発生する消化管障害のうち晚期障害 は潰愓, 出血, 腸管狭窄や㾇孔形成などがみられ, 組 織学的に小動脈の狭小化や血管报張とともに組織反応 がそしいため難治性である。したがって外科的治療の 対象になるすのがしばしばであるが，原疾患に加え放 射線照射による影響が加味され，治療困難な症例が多 い.

最近私共は肝門部および骨盤腔内への放射線照射に よる消化管障害10例を経験したので症例の概要と治療 上の問題点について報告する.

\section{症例}

過去 5 年間に私共の経験した放射線治療による消化 管障害は表 1 〜 に示寸10例で, 男性 2 例, 女性 8 例, 年龄は $47 \sim 80$ 歳, 平均 64.3 歳であった。

原疾患および放射線治療：原疾患は肝門部胆管癌 2
例, 子宮癌 7 例, 前立腺癌 1 例であった。肝門部胆管 癌は 2 例之も切除術後肝門部を中心に $2,200 \mathrm{rads}$, 4,000rads の照射が行なわれ, 子宮癌は 6 例が非手術 例で 1 例のみ子宮摘除後骨盤腔内人 $5,000 \sim 6,000 \mathrm{rads}$ の照射が行なわれ，前立腺癌も非手術例で骨盤腔内人 6,000rads の照射が行なわれている. 尚照射方法は全 例に明らかではないが，主にLinacによる外部照射で ある。

放射線障害：放射線障害は胃・十二指腸潰澔 2 例, 腸閉塞 4 例, 消化管出血 4 例で, 照射から障害発生ま での期間は最短 3 カ月, 最長 14 年と多岥にわたってい る。肝門部照射による胃・十二指腸潰瘍は 3 力月， 5 カ月と比較的短期間で発生しているか，骨盤腔内照射 に上る腸閉塞（回腸 2 例， S 状結腸 1 例，直腸 1 例） は照射後 1 年 7 カ月から14年之長期経過後の発生であ る.消化管出血はいずれも直腸からの出血で, 照射後 
表 1 肝門部照射例(核埕)

\begin{tabular}{|c|c|c|c|}
\hline 症 & 例 & 1 & 2 \\
\hline \multirow{2}{*}{\multicolumn{2}{|c|}{ 年性 }} & 64歳 & 57歳 \\
\hline & & 우 & $\hat{\delta}$ \\
\hline \multicolumn{2}{|c|}{ 原 疾 } & 肝門部胆管癌 & 肝門部胆管癌 \\
\hline \multicolumn{2}{|c|}{ 術 } & $\begin{array}{l}\text { 晘左葉切除兼 } \\
\text { 肝門部胆管切除 }\end{array}$ & 肝門部胆管切除 \\
\hline \multicolumn{2}{|c|}{ 照 射 法 } & 外部照射 & 外部照射 \\
\hline \multirow{2}{*}{\multicolumn{2}{|c|}{ 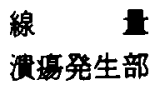 }} & $4000 \mathrm{rad}$ & 2200rad \\
\hline & & 十二指腸 & 胃 \\
\hline \multicolumn{2}{|c|}{ 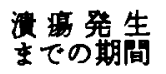 } & 3 ヶ月 & 5 ケ月 \\
\hline 術 & 式 & I & 1 `月後胃切除 \\
\hline 転 & 㛿 & 3 ヶ月後再発死 & 良好 \\
\hline
\end{tabular}

表 2 骨盤内照射例(腸閉塞)

\begin{tabular}{|c|c|c|c|c|}
\hline 症＼cjkstart例 & 3 & 4 & 5 & 6 \\
\hline 年 & 55歳 & 47歳 & 70嵅 & 68歳 \\
\hline 性 & 우 & f & 우 & ㅇ \\
\hline 原 患 & 子宮癌 & 子宮癌 & 子宮癌 & 子宮痘 \\
\hline 術 式 & 子宮摘除 & I & 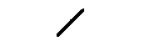 & $/$ \\
\hline 照 射 法 & 外部照射 & 外部照射 & 外部照射 & 外部照射 \\
\hline 線 & $5000 \mathrm{rad}$ & $6000 \mathrm{rad}$ & $5000 \mathrm{rad}$ & $6000 \mathrm{rad}$ \\
\hline 閉 塞 部 & 回腸 & 回腸 & $\begin{array}{c}\text { S状結咀 } \\
\text { (穿孔) }\end{array}$ & 直腸 \\
\hline 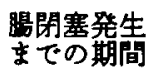 & 1 年 7 ヶ月 & 14 年 & 1 年 9 ヶ月 & 5 年 \\
\hline $\begin{array}{l}\text { 手術までの } \\
\text { 期 }\end{array}$ & 1 年 1っ月 & 6 ヶ月 & 2 年 4 ヶ月 & $\gamma$ \\
\hline 術 & $\begin{array}{l}\text { 回腸切除 } \\
(80 \mathrm{~cm})\end{array}$ & $\begin{array}{c}\text { 回鹏切除 } \\
(80 \mathrm{~cm})\end{array}$ & 人工肛門 & I \\
\hline 枟 & 良好 & 良好 & $\begin{array}{c}\text { 3r月後 } \\
\text { 他病死 }\end{array}$ & 1 \\
\hline
\end{tabular}

表 3 骨盤内照射例（出血）

\begin{tabular}{|c|c|c|c|c|c|c|}
\hline \multicolumn{3}{|c|}{ 症例 } & 7 & 8 & 9 & 10 \\
\hline 年 & & 齢 & 75葴 & 71葴 & 56歳 & 80歳 \\
\hline & 性 & & $\hat{\delta}$ & 우 & 우 & 우 \\
\hline 原 & 疾 & 患 & 前立腺癌 & 子宮癌 & 子宮痁 & 子宮癌 \\
\hline 術 & & 式 & / & Y & / & Y \\
\hline 照 & 射 & 法 & 外部照射 & 外部照射 & 外部照射 & 外部照射 \\
\hline 線 & & 量 & $6000 \mathrm{rad}$ & $5000 \mathrm{rad}$ & $6000 \mathrm{rad}$ & $6000 \mathrm{rad}$ \\
\hline & 血 & 部 & 直腸 & 直䭪 & 直 腸 & 直 腸 \\
\hline 出血 & まて & $\begin{array}{l}9 \\
\text { 間 }\end{array}$ & 9 ヶ月 & 6 ヶ月 & 1 年 4 力月 & 1 年 1 ケ月 \\
\hline 輸 & & 血 & 巴 & $\oplus$ & $\oplus$ & 曲 \\
\hline 人工 & $\begin{array}{l}\text { 䀴門造 } \\
\text { の 期 }\end{array}$ & 告言盇 & 月 & 3 カ月 & 1 年 7 ヶ月 & 1 ヶ月 \\
\hline 以 & の出 & & p队減少 & 減 & 少 & $\begin{array}{l}\text { 不 変 } \\
\text { 直腸切断術 }\end{array}$ \\
\hline
\end{tabular}

6 カ月から1年 4 カ月で出血が始まっている.

放射線障害発生後の経過：全例に対し緩下剂，止血
剂，副腎皮質ホルモン，サラン゙ピン，抗潰瘍凧等によ る保存的治療が試みられ症状の軽快した症例むみられ たか，長期間の治療効果は認められなかった。放射線 照射による障害消化管の切除がなされたのは10例中 4 例である。肝門部照射後の胃潰瘍で溃湯発生 1 力月後 胃切除 1 例, 腸閉塞の5ち回腸閉塞の 2 例は発症後閉 塞症状の増強がみられ 6 力月 1 年 1 力月後に回腸部 分切除が行なわれた. 直腸出血 4 例は全例人工肛門造 設がなされ，5ち出血量に減少㑯向のない1例に值腸 切断術が行なわれた。 以上の障害消化管切除例では手 術時癌再発を思わせる所見を認めず，術後の释過も良 好であった。障害消化管非切除の 6 例についてみると， 肝門部照射の十二指腸潰場は治瘾傾向がないまま右肝 管空腸吻合部の癌再発により 3 カ月後死亡. 解剖で十 二指腸球部に ul IV 巨大潰湯が認められた。腸閉塞の 5 ち直腸閉塞例は保存的に経過観察中で， $\mathrm{S}$ 状結腸狭 窄例は穿孔による膿瘍形成がみられ，人工肛門および ドレナージで一時軽快したものの 3 カ月後巨大腃動脈 瘤で死亡した。直腸出血 3 例は人工肛門造設後出血量

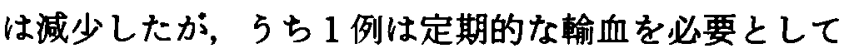
いる。手術時の検索では癌再発はみられなかった。 次に潰瘍, 腸閉塞, 出血の各 1 例ずつを紹介する。

症例 $2: 57$ 歳男珄. 昭和57年 7 月肝門部胆管癌のた め胆管切除, Roux-Y にて胆管空腸吻合を 5 け, 術後肝 門部を中心に Linac 照射が開始された。照射早期から 上腹部不快を訴えるため2,200radsで中止したか， 5 カ月後胃潰煌が認められた。保存的治㞠で効果なく 1 カ月後胃切除を施行, 穿通性の潰煬で, 組織学的に漬 瘍周囲に炎症性細胞浸潤は乏しく治瘦傾向はみられな かった（図 1 A, B) 癌再発はなく術後の経過は良好で ある.

症例 $3 ： 55$ 歳女性. 昭和54年 6 月, 子宮癌（子宮頝 部, 扁平上皮癌）の診断で子宮摘除術後 Linac 5,000 rads の外部照射が行なわれた。昭和56年 1 月頃から腹 部膨满, 呕吐など腸閉塞症状が出現し, 保存的治療で 軽快するも同様の症状が次第に频回となり，昭和57年 3 月当科入入院した。 入院後 long tubeを挿入し，1 日 1,000 2,000ml 吸引し减少傾向がみられないため 入院12日目に手術を施行した。回腸に狭窄部がみられ 約 $80 \mathrm{~cm}$ の回腸切除を行ない, 摘出標本では高度の狭 窄部がみられた。組織学的に粘膜の萎縮, 粘膜以下全 層にわたりコラーゲンの増生をとすな5線維化や小動 脈では内膜肥厚による内腔の狭小化が著明であった （図 $2 \mathbf{A}, \mathbf{B}, \mathbf{C}$ )。癌再発はなく術後の経過は良好であ 

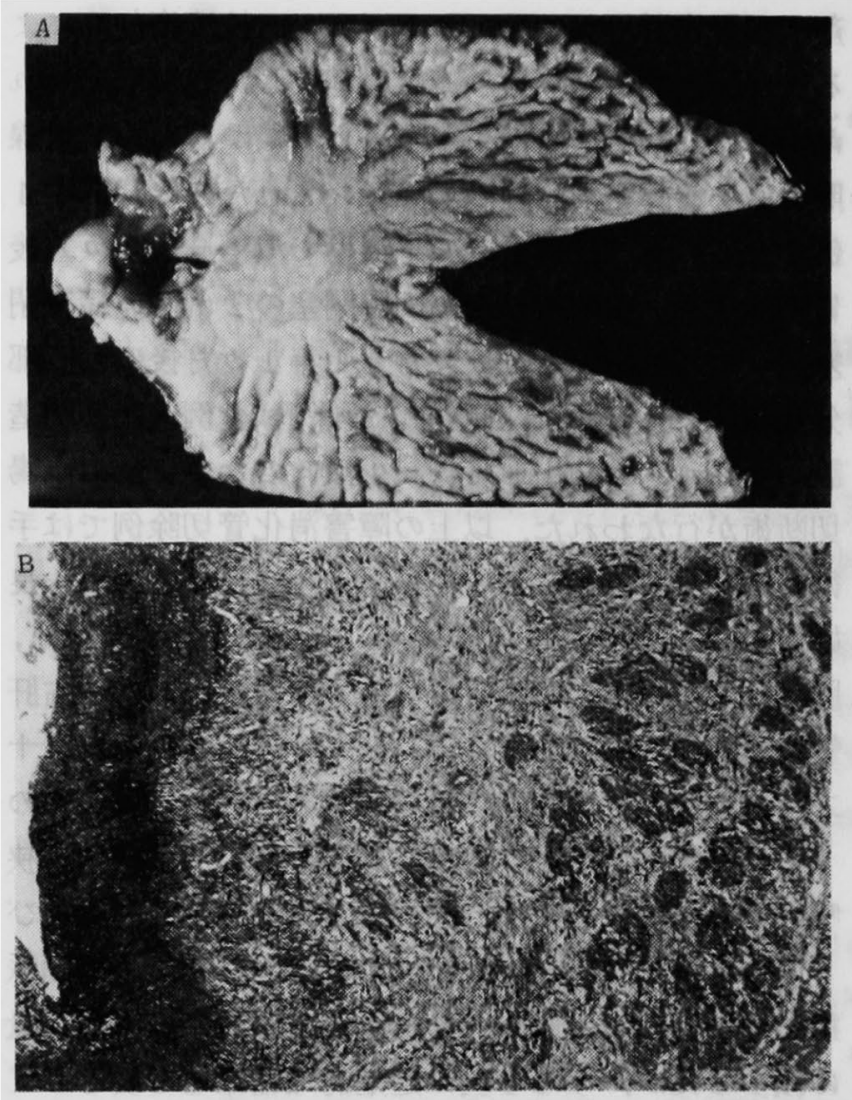

図 1 症例 2

A：切除標本，溃晹を認める，B：組織像。溃晹底 であるが，炎症細胞浸潤は軽度である(H.E. ×40)。

る.

症例 $10 ： 80$ 歳女性。昭和57年 9 月子宮癌(子宮頝部, 扁平上皮癌) と診断, Linac 5,000rads の外部照射が行 なわれた，以後補助療法が続けられ良好に程過してい たが，昭和58年10月中頃から鮮血の肛門出血がみられ 当科入入院した。 入院時 $\mathrm{Hb} 6.1 \mathrm{~g} / \mathrm{dl}$, へマトクリット 18.9\%と高度の負血を示したが，血清 CEA 值2.0ng/ $\mathrm{ml}$, 婦人科的に異常なく，癌再発は否定的であった。大 腸 fiber で直腸は全体に発赤浮腫状で浅いビランが られ放射線照射による大腸炎からの出血と考光，電気 凝固，トロンビンや副腎皮質ホルモンの注腸など止血 を試みたが効果なく，1カ月後局所安静のため人工肛 門を造設した。止血効果は約 1 カ月間のみで再び持続 的な出血をきたすようになり，翌年 2 月腹会陰式直腸 切断術を施行した，入院後手術までの間の輸血量は合 計38pack であった. 切除標本で直腸は肛門近くまで厚 く浮腫状で粘膜は発赤し，明確な潰瘍はみられず，組 織学的には萎縮した直腸粘膜と，粘膜から粘膜下層に かけて毛細血管の著しい拡張が特徵的であった（図 3 A, B).

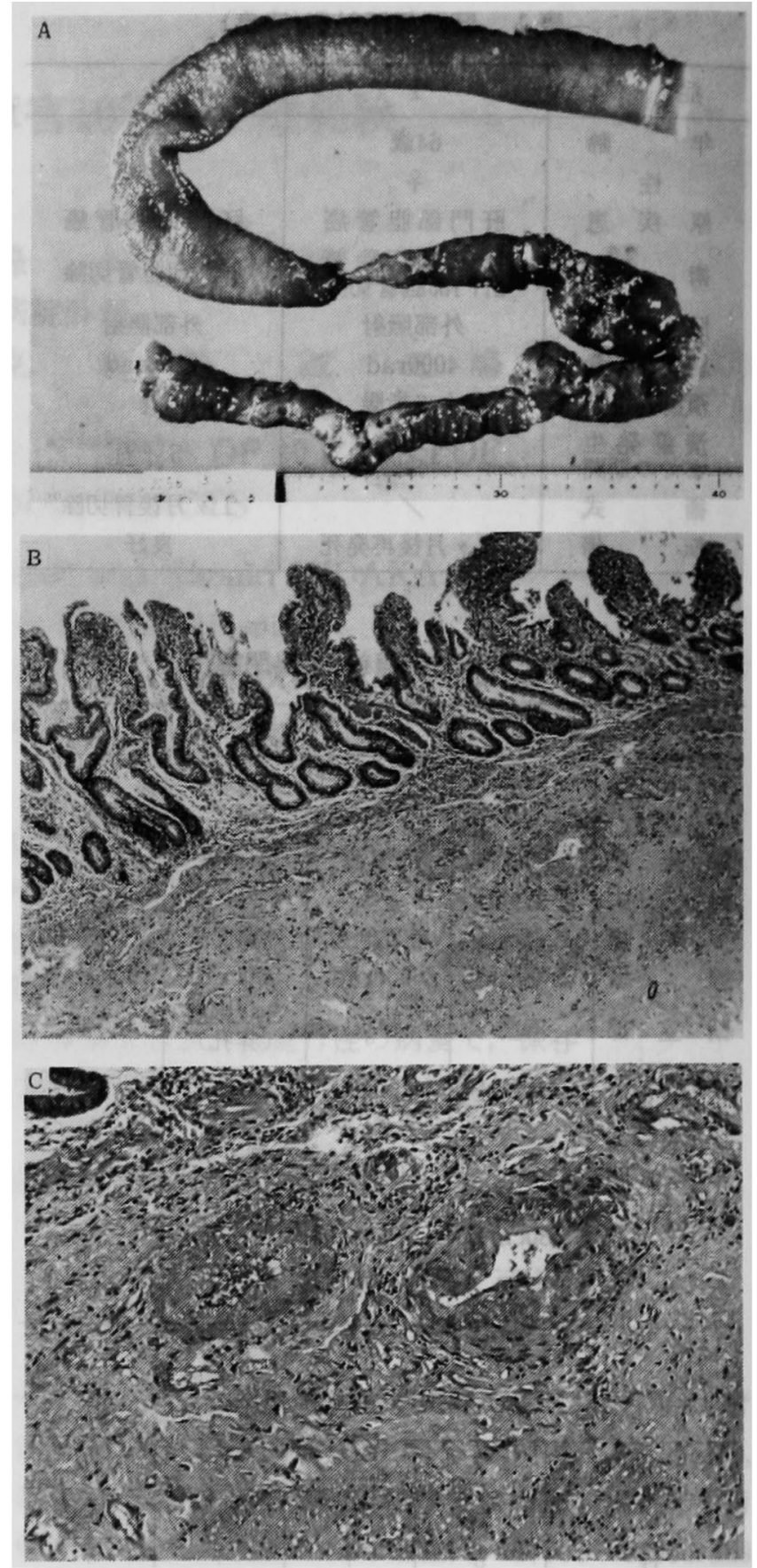

图 2 症例 3

A：切除標本. 高度な㹟窄部があり，散在性に放射 線または缯着によると思われる変化がみられる。 $\mathrm{B}$ ：組䋨像，粘萎縮之粘膜以下全層にわたりコ ラーゲンの増生をともな5線維化が著明である(H. E. $\times 40) . C$ : 小動脈の内膜肥厚之内腔の狭小化が認 められる (H.E. $\times 100)$

\section{考察}

放射線照射による消化管障害は一般的に早期障害と 晚期障害に大別され，前者は turn over の早い粘膜を 中心としたすのであるが，後者はturn overの暑い vasculo connective tissue の障害で'1) 難治性のすのが 

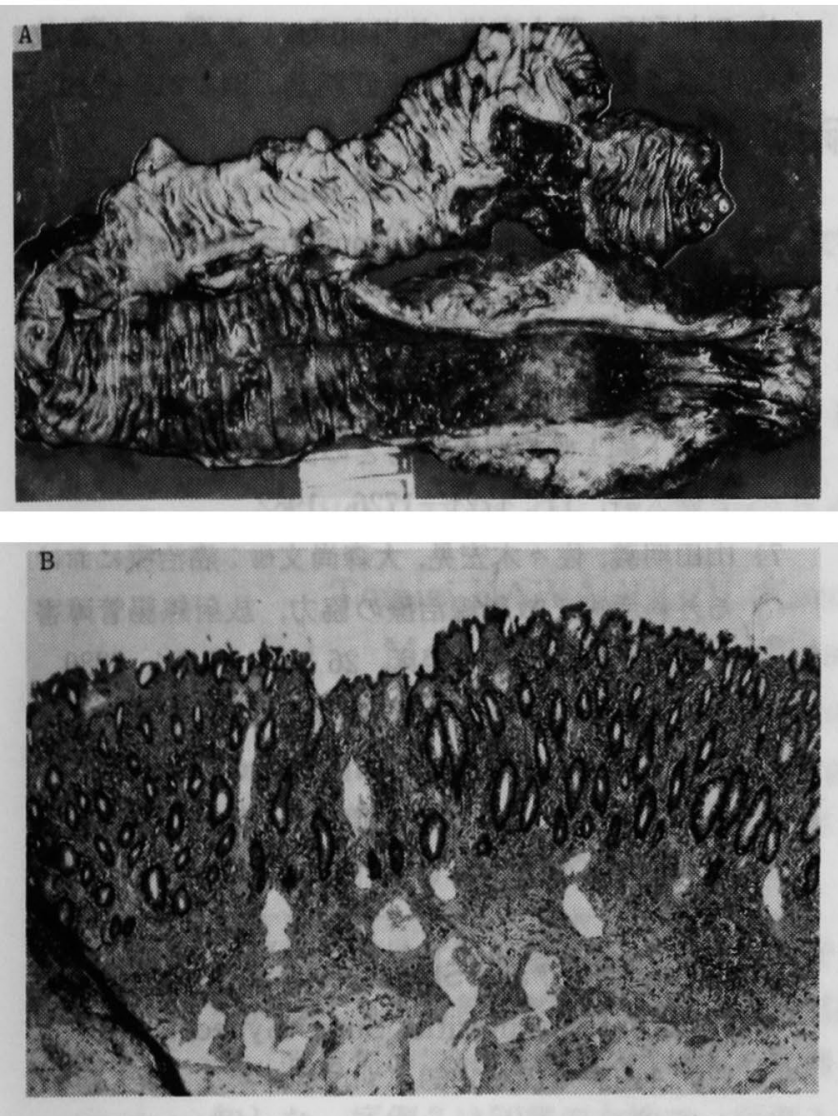

图 3 症例10

A：切除標本. 直腸は肛門まで厚く浮腫状で, 広範 な粘膜の变化を認める. B : 組織像, 粘膜から粘膜下 居にかけて手細血管の著明な払張を認める(H.E. $\times$ 40).

多い，発症時期は照射後 $1 \sim 2$ 年の間に圧倒的に多い

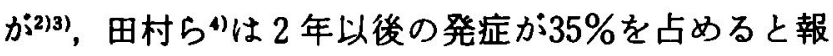
告し，さらに照射後10年を経過した消化管です腸管の 炎症性変化が持続し，多核白血球の活動がみられるこ とより5), 長期経過後も進行性の病変を考虑する必要 がある. 照射開始時の初期症状から晚期障害のハイリ スク症例を予知し，何らかの対応策を講ずる考案もな されているが6)，ひとたび基質的な変化が生ずると保 存的治療の長期効果は期待できないようである。自験 10 例中 2 年以内の発症が 8 例 (80\%) をしめているが, 多くの症例で発症後各症状の増強がみられ保存的治療 の長期有効例はなく，徐々に進行する変化であること を示し，切除標本では細動脈の内膜肥厚による内腔の 㹟小化，毛細血管の拡張やうっ血，あるいは粘膜の萎 縮，粘膜下組織のコラーゲン増生をともなら線維化や 炎症細胞浸潤の欠除などの所見が認められ，homeostasisによる組織修復能の低下を物語るすのといえよ 5.
本症に対する治㞠はまず保存的治療を行ない，無効 例に対し外科的治療がなされいるが7)，外科的治療 法として障害消化管を積極的に切除する方法と，障害 消化管には手術操作を加えず bypass 手術や人工肛門 造設術を行なら方法に別れる。放射線照射による晚期 障害消化管の不可逆性変化を考えるならば前者の方法 は理想的な手術術式であるが，，障害消化管に直接手 術操作を加えることは手術そのむのが容易でなく，前 回の手術の影隌や骨盤内照射例ではfrozen pelvisの 状態も念頭に置かなければならず，実際には後者の人 工肛門造設術やbypass手術しか出来ない症例が多 (、7)B．自験例でも全例に対し保存的治療が行なわれ， 直腸出血には可及的人工肛門造設が施行された。しか しながら一時的に症状の改善が得られたことからこれ らの治療法に期待し，かえって病悩期間を延長させる 結果になったことは反省すべきであろう。

障害消化管を切除する場合，障害の部位，範囲およ びその程度により適当な手術術式の選択が必要とな る. 胃十二指腸溃瘍では通常行なわれている胃切除で よいが，小腸障害例は小腸を十分切除し，切除断端が 照射による影響のないことを確認すべきである，小腸 は大腸にくらへ可動性があるため障害を受けにくいと いわれているが9，一方照射による影䈉の範囲が広が ることが考えられる. Localio ら ${ }^{101}$ は切断端が正常で あったにもかかわらず，数年後吻合部に前回同様の放 射線障害を生じたことを報告し，掛川ら゙は切除断端 決定のため生検による各種染色で組織学的にコラーゲ ン増生や，血管内膜の変化などから切除線を決定すべ きと述へている。自験症例 $3 ， 4$ は肉眼的障害範讲は 比較的短いと思われたか，各々 $80 \mathrm{~cm}$ の小腸が切除さ れている.

直腸障害に対する切除術は直腸切断術, 肛門括約筋 を温存する貫通法や直腸切除兼人工肛門造設術（ハル トマン氏手術）などが考えられる。自然肛門を利用す る立場から貫通法が推奖されているがク，この場合手 術適応を钴密にすべきである。すなわち原疾患の再発 が骨盤内になく，両側吻合部に放射線障害がなく，ま た十分な肛門機能が認められることなどが条件とな る11).したがって現実にはかかる術式は困難なことが 多い. 自験症例10では直腸切断術がなされているが, 摘出標本で肛門近くまで放射線照射による変化がみら れることや障害腸管曠置例でいくつかの問題が残され ていること”から，結果的には直腸切断術が必要で あったと考えられる。 
放射線照射による晚期消化管障害はひとたび発生す ると進行性の変化で, 保存的治㞠による完治は望めな い. 障害消化管の切除が理想的とはい克, 一塊となっ た腸管の切除や大量切除ともなると躊躇されるであろ 5.自験例では障害消化管の切除された 4 例で手術後 の経過は良好であるが，死亡例す含め他の症例は長期 間各症状の消失はみられなかった。したがって今後そ の予防対策についても十分な検討が必要であると思わ れる。

\section{結語}

放射線照射後の消化管障害10例について治療の概要 を報告するとともに，治療上の問題点について若干の 考察を加えた。

本論文の要旨は第45回日本臨床外科医学会総会（1983年 11月広島）にて発表した。

\section{文献}

1) 中神一人, 北島正是, 田辺徹也他：放射線治療後の 腸管障害, 手術例の検討, 外科, $40: 456-460$, 1978.

2) Gilinsky, N.H., Burns, D.G., Barbezat, G.O., et al.: The natural history of radiation-induced proctosigmoiditis: An analysis of 88 patients. Q. J. Med., 52: 40-53, 1983.

3）掛川暉夫, 磯本浩晴, 山内 胖他：照射性直腸炎の 治㞠, 消化器外科, 4:1493-1501, 1981 .
4）田村利和, 蔵本守雄, 井川和彦他：教室における放 射線直腸炎の検討，大腸肛門誌，34：216-219， 1981.

5) Bruneton, J.N., Faure, X., Bourry, J., et al. : A radiologic study of chronic radiation-induced injuries of the small intestine and colon : Fortschr. Röntgenstr., 136 : 129-132, 1982.

6）植田国昭, 宮川 昇，村上 章他：放射線治療にお ける下沟と晚期腸管障害との成連について，産科 と婦人科, $11: 1721-1726,1982$.

7）山田明義, 佐々木宏晃, 大森尚文他：癌治療におけ る外科手術と放射線治療の協力，放射線腸管障害 一外科から一, 癌の臨床, $26: 996-1004,1980$.

8）田中承男, 内藤和世, 能見伸八郎他：放射線腸管障 害の手術経嵞, 日臨外，44：112-117，1983.

9）旭 博史，佐々木純，一色道夫他：放射線腸炎に上 るイレウスの 5 例, 日消外会誌, $14: 117-122$, 1981.

10) Localio, S.A. and Stone, A.: Surgical aspects of radiation enteritis. Surg. Gynecol. Obstet., 129 : 1163-1172, 1969.

11）森谷宜晧, 小山靖夫，北條度一：放射線直腸障害に 対する肛門括約笳温存手術一貫通法の手技・有用 性と 4 症例報告一，大腸肛門誌，35：502-508， 1982. 